Supplement of Biogeosciences, 12, 1993-2001, 2015

http://www.biogeosciences.net/12/1993/2015/

doi:10.5194/bg-12-1993-2015-supplement

(C) Author(s) 2015. CC Attribution 3.0 License.

(c) (i)

Supplement of

\title{
Biostratigraphic evidence for dramatic Holocene uplift of Robinson Crusoe Island, Juan Fernández Ridge, SE Pacific Ocean
}

P. Sepúlveda et al.

Correspondence to: L. E. Lara (luis.lara@sernageomin.cl) 
1 Biostratigraphic evidence for dramatic Holocene uplift of

2 Robinson Crusoe Island, Juan Fernández Ridge, SE

3 Pacific Ocean

5 P. Sepúlveda ${ }^{1}$, J. P. Le Roux ${ }^{1,2}$, L.E. Lara ${ }^{3 *}$, G. Orozco $^{3,2,1}$, V. Astudillo ${ }^{1}$

6 [1]\{Departamento de Geología, FCFM, Universidad de Chile\}

7 [2] $\{$ Centro de Excelencia en Geotermia de los Andes, Santiago, Chile\}

8 [3]\{Volcano Hazards Program, Servicio Nacional de Geología y Minería, Santiago, Chile\}

9 Correspondance to: Luis E. Lara (luis.lara@sernageomin.cl)

\section{Abstract}

A study of the biostratigraphy and sedimentology of Holocene deposits on Robinson Crusoe Island (RCI) on the Juan Fernández Ridge (JFR) indicates that a dramatic but localized uplift occurred since 8,000 BP, at a rate of about $8.5 \mathrm{~mm} / \mathrm{yr}$. In fact, supratidal flats and sand layers with marine gastropods (mostly Nerita sp.) are now exposed $c a .70 \mathrm{~m}$ a.s.l., and covered by transitional dunes. The last volcanic activity on RCI occurred at $c a$. $0.8 \mathrm{Ma}$ (active hotspot located $280 \mathrm{~km}$ further west) and there is no sign of a compensating bulge that explains this uplift, isobaths of the sea floor instead suggesting general subsidence. However, modeling indicates that large-scale landslides followed by isostatic rebound are a viable explanation, partially reflected in the low-resolution bathymetry of the area.

\section{Introduction}

The Juan Fernández Ridge (JFR), located on the Nazca Plate in the Pacific Ocean off central Chile (Fig. 1), is an $800 \mathrm{~km}$ long seamount and volcanic island chain extending E$\mathrm{W}$ at latitude $33^{\circ} \mathrm{S}$. It has been interpreted as the expression of a fixed hotspot (Von Heune 
et al., 1997; Montelli et al., 2006) related to a primary mantle plume in the sense of Courtillot et al. (2003) or as part of a 'hot line' (Bonatti et al., 1977). According to the plume hypothesis, active diapiric plumes arising from the core-mantle boundary form submarine volcanic plateaux or island chains within oceanic plates. As the plate moves away due to sea-floor spreading, these volcanoes are extinguished and new volcanic edifices arise over the active hotspot, forming age progressive island chains such as the Hawaiian-Emperor seamount chain. The plume hypothesis has been challenged, however, because some of its predictions have not been confirmed by observation, and plate tectonic processes are thought to be playing a role (e.g., Foulger, 2010).

A remarkable feature of hotspot ocean islands is their complex history of vertical displacement (e.g., Ramalho et al., 2013). Uplift and subsidence, as earlier noted by Charles Darwin in the 19th century, respond to a number of large-scale processes better known at present as the growth of the underlying swell and the related isostatic rebound, bulging effects resulting from loading of nearby islands and seamounts (e.g., Bianco et al., 2005), changes of density in the mantle, intrusions at the base of the edifice (e.g., Klügel et al., 2005) and gradual cooling of the lithosphere. However, giant landslides can also trigger sudden uplift as inferred for archetypical hotspot volcanoes such as Hawaii (e.g., Smith and Wessel, 2000).

Although most of the active oceanic islands are subsiding (as the Surtsey island in the last decades; e.g., Moore et al., 1992), here we present evidence for a very high Holocene uplift rate of Robinson Crusoe Island (RCI) and discuss a possible mechanism together with implications for the long-term evolution of this ocean island.

\section{Geological and geomorphological background}

The JFR is an island-seamount chain largely formed by the Miocene (ca. $9 \mathrm{Ma}$ ) O'Higgins guyot and seamount (Von Heune et al., 1997), with lavas dating back to ca. 4 Ma on RCI and nearby Santa Clara Island (Fig. 1), and ca. 1 Ma on Alejandro Selkirk Island about 120 km away (Farley et al., 1993). The relief on the western, arid part of RCI is characterized by coastal cliffs bordering a terrace at about $70 \mathrm{~m}$ a.s.l., which is especially well developed in the southwestern panhandle (Fig. 1). This terrace is formed on top of a post-shield 
volcanic platform of middle Pleistocene age from which pyroclastic cones emerge, reaching a maximum elevation of $915 \mathrm{~m}$ (Lara et al., 2013). Holocene sedimentary deposits are restricted to the terrace in the vicinity of Tierra Blanca Bay. The latter name is applied (in Spanish) to a succession described by Morales (1987) as poorly consolidated, calcareous sandstones at the base grading upward into tuffaceous sandstones with numerous fossils. In the transition zone are Acanthina and Lima fossils with bryozoa fragments, whereas the tuffaceous sandstones host Luccinea, Distoechia, Bythinia, Orcula, Tropicorbis, Ena, and Cyrena spp. indicating a Pleistocene-Holocene age, based on a similar fossil assemblage on the continent at this latitude (Covacevich, 1971; Valenzuela, 1978). The Bahía Tierra Blanca Formation has its base at a variable elevation but generally at $c a .70 \mathrm{~m}$ above the present mean sea level, where active, incipient barchan dunes (Morales, 1987), partially rework the succession described above.

\section{Material and Methods}

Field campaigns were carried out on RCI in 2011-2013, during which geological mapping was undertaken, stratigraphic sections were measured, and samples were collected for further analysis. Laboratory work consisted of fossil identification, petrographic microscopy, sieve and Mastersizer 2000 (Malvern Instruments, Malvern, United Kingdom) analysis of the sediment grain-size distribution, and radiocarbon dating (Beta Analytic Inc., Miami, Accelerator Mass Spectrometer) of gastropods. The latter were collected mostly from sites 1 and 5 (Fig.1). Several specimens were hand-picked from bulk samples and three were selected for dating based on their stratigraphic position and systematics. AMS radiocarbon dates were first corrected for the global marine reservoir effect (e.g., Ulm, 2006) with the Marine IntCal09 calibration program (Reimer et al., 2009). For the localized reservoir correction a Delta- $R$ value of $373 \pm 76$ from a site nearby (http://radiocarbon.pa.qub.ac.uk/marine/) was used. Elevations were measured with a dGPS Trimble ${ }^{\circledR N e t R S}{ }^{\circledR}$ and barometric altimeters with respect to the current sea-level and corrected for the regional sea level and daily variation (http://www.shoa.cl/mareas/tablademarea.html) with a nominal uncertainty of $5 \mathrm{~m}$.

\section{Depositional environments}


Four lithostratigraphic units and three lithofacies were identified in the Bahía Tierra Blanca Formation, which reaches a total thickness between 2 and $4 \mathrm{~m}$ at any specific locality (Fig. 2).

Unit 1 is largely composed of facies 1 , which discordantly overlies weathered, basaltic lavas. It consists of very poorly consolidated, slightly calcareous, reddish brown to reddish purple deposits ranging in size from very fine sandstone to claystone. Their composition is made up of volcanic ash mixed with the underlying, weathered lava material. These deposits contain up to $2 \%$ bioclasts (mostly marine bivalves) together with pellets. The most striking feature of this facies is ubiquitous, up to $1 \mathrm{~m}$ diameter teepee structures, which display prominent edges elevated 3-5 $\mathrm{cm}$ above the central parts (Fig. 2). The cracks have been filled in by sands from the overlying unit. Locally, shallow channels and rill marks are present.

While the reddish to purplish brown color suggests a mainly subaerial environment, the presence of teepee structures with elevated rims indicate frequent flooding and drying cycles. These, as well as the occurrence of pellets, are typical of supratidal flats (e.g., Assereto and Kendall, 1977), which concurs with the presence of shallow channels probably reflecting tidal creeks. The general scarcity of hard-shell fossils in this facies can be interpreted as representing a generally hostile environment subjected to frequent dry periods between spring high tides, followed by seawater flooding that would kill landdwelling snails and other organisms. Marine shells washed in during spring high tides would probably accumulate along the shoreline. Soft-bodied forms more tolerant to such conditions, on the other hand, would not be preserved in such an oxidizing environment.

Facies 2 is present in units 2 and 3, which differ mainly in the darker brown color of the latter due to a thin brownish film coating the grains. Both units 2 and 3 show large-scale, low angle planar cross-bedding and horizontal lamination, but in unit 3, high-angle planar and trough cross-bedding are locally present (SM, Fig. A). The 1-2 cm thick cross-beds are formed by alternating light and darker-colored grains without any evident gradation. Rhizocretions are present in the uppermost parts of both units, where individual forms may reach $1.5 \mathrm{~m}$ in length (Fig. 3). Although rhizocretions and vertebrate burrows are generally rare, some parts have a fairly high density of the former. Unit 2 is capped locally by whitish 
calcrete indicating incipient pedogenesis. Gastropods such as Succinea, Fernandezia, and Nerita occur in the middle to upper part of unit 2. Petrographically, the sandstone is well sorted with subrounded grains, lacking a matrix, and cement being only locally present. Bioclasts compose around 55\% of the rock, including brachiopod and pelecypod fragments, echinoderm spines, bryozoa, red algae, foraminifers, and sub-rounded pellets. The rest of the composition is made up of volcanic fragments and minerals such as K-feldspar, plagioclase, clinopyroxene, and olivine, with rare quartz. Grain-size analysis of several samples from this facies shows a small traction load, a prominent and very well-sorted saltation load, and a medium- to well-sorted suspension load (SM, Fig. B). This facies is interpreted as reflecting coastal eolian deposits perhaps locally affected by weak wave action. This is supported by the reddish brown color of the sandstones, their predominantly fine grain-size with cumulative curves typical of wind-blown deposits, and the presence of the land-dwelling snails Succinea and Fernandezia, as well as root and burrow systems. The horizontally laminated strata probably formed in sand sheets between low dunes, which might have been parabolic in shape as suggested by the dominance of low-angle planar cross-bedding. Some were subsequently converted into dikaka dunes by vegetation. Some low-angle cross-bedding might represent reworking by dissipated wave action during storms and spring high tides along the landward edges of wide supratidal flats. This could also explain the presence of thick-shelled Nerita (a marine species) in Unit 2. The presence of fragmented marine invertebrates indicates a marine source for most of these sands, which suggests that they formed at a low elevation above sea level.

Facies 3 is composed of greyish white, medium sorted sandstones interbedded with gravel. The sandstones consist of bioclasts (45-57\%) mostly represented by marine shell fragments including bivalves, gastropods such as Succinea, bryozoa, algae, and foraminifers, together with lithic volcanic fragments (27-45\%) and volcanic minerals such as pyroxene, olivine, and felsic minerals (10-17\%). The gravels are greyish brown and matrix- to clastsupported, with the clasts reaching up to $5 \mathrm{~cm}$ in diameter. They are mainly volcanic and angular. Locally, calcretes are present at the top of this facies. This facies clearly represents fluvial deposits, probably consisting of shallow, quick-flowing ephemeral streams with gravelly channels and sandy bars. These most likely drained exposed basalts on the fringes of the eolian sand sheets, but also reworked the latter to incorporate the marine bioclasts. 


\section{Radiocarbon dating}

Specimens of Nerita (SOM, Fig. C) from the eolian sandstones of unit 2 yielded calibrated radiocarbon ages between 8,320 and 8,030 BP (conventional radiometric age of 7,860 \pm 40 years BP). Values corrected for the global marine reservoir effect (with a local Delta-R of $373 \pm 76$ as obtained for the similar entry at http://radiocarbon.pa.qub.ac.uk/marine/ correspond to 7,550 \pm 90 years BP (see Table 1). These marine species were probably reworked from the supratidal flats of unit 1 and would thus represent the age of the latter. On the other hand, land-dwelling species as Succinea and Fernandezia (e.g., Odhner, 1922) from units 3 and 4 gave calibrated radiocarbon ages between 5,440 and 5,090 years BP $(4,580 \pm 30$ conventional years BP) and 7,680 and 7,580 years BP $(6,790 \pm 40$ conventional years BP), respectively.

\section{Discussion}

The stratigraphic succession of the Bahía Tierra Blanca Formation suggests that supratidal conditions existed in the southwestern panhandle of RCI between 8,320 and 8,030 years BP (horizons with Nerita). It is unlikely that the tides reached more than 1-2 m above the mean sea level, because topographic tide-enhancing conditions such as funnel-shaped estuaries could not have existed due to the absence of large rivers on this part of the island. These supratidal flats were encroached upon by eolian coastal plain deposits at around 5,430 years BP (horizons with Succinea and Fernandezia) and finally fluvial sedimentation as the sealevel receded further during the late Holocene Climatic Optimum (Davis et al., 2003; Koshkarova and Koshkarov, 2004), when the southwestern panhandle would have received more rain. The present elevation of the supratidal deposits on a marine terrace at $70 \mathrm{~m}$ a.s.l. indicates a very rapid relative sea-level fall since that time. Furthermore, it can be assumed that the eolian deposits of units 2 and 3 were also not more than a few meters above the tidal flats, as they had apparently been reworked locally by waves. This is supported by the low-angle cross-bedding typical of beaches and the presence of reworked Nerita. The latter could not have been blown uphill by wind, considering that they reach up to $1 \mathrm{~cm}$ in 
diameter (Appendix A). Assuming that they were not more than $2 \mathrm{~m}$ above the tidal flats or beaches, a relative sea-level fall at least $8.5 \mathrm{~mm} /$ year is implied.

Eustatic sea-levels have been well below the present-day level over the last 20,000 years (Bindoff et al., 2007; Fleming et al., 1998). In Tahiti and almost all other regions of the world where detailed records exist (e.g., Lambeck et al., 2002), there are indications that the sea-level at 8,000 years BP was about $15 \mathrm{~m}$ below that of the present (Fleming et al., 1998; Milne et al., 2005). This rules out an eustatic highstand at the time. A mean uplift rate of around $8.5 \mathrm{~mm} / \mathrm{yr}$ is extremely high, considering that the average rate of uplift of the Andes has been only about 0.2-0.3 mm/yr since the Late Miocene (Gregory-Wodzicki, 2000) and uplift rates of other ocean islands were $<0.33 \mathrm{~mm} / \mathrm{yr}$ (e.g., in the oldest Hawaiian islands as reported by McMurtry et al., 2004 and references therein). Ocean islands with evidence of significant freeboard (e.g. Cape Verde) show uplift rates $<0.4$ $\mathrm{mm} / \mathrm{yr}$ (Ramalho et al., 2010a; 2010b). This high vertical displacement rate is only comparable with the subsidence rate of the active Hawaii Island, which sinks at $c a$. 2.6 $\mathrm{mm} / \mathrm{yr}$ (McMurtry et al., 2004). No further evidence of such an uplift is recorded at RCI, which in turn suggests a very localized process.

The dramatic Holocene uplift of RCI cannot be explained as a flexural response to the loading exerted by the edifices created by the active hotspot. Isobaths (after Becker et al., 2009; see also Rodrigo and Lara, 2014) show that the sea floor north of the JFR descends from 3,800 m northwest of Alejandro Selkirk to about 4,000 m north of the latter, from where it declines further to reach 4,200 m north of RCI and 4,300 m northeast thereof. There is thus no direct evidence for the existence of a bulge upon which RCI would be situated. The bathymetry in fact shows a negative anomaly for this part of the oceanic crust. General subsidence could occur in the wake of a mantle plume migrating away from a particular area, as this part of the lithosphere would no longer be sustained by it, combined with the load exerted by the shield volcano. The generation of new islands and seamounts above a fixed mantle plume could cause loading and subsidence of the crust accompanied by the formation of an adjacent, compensating bulge, and hence local uplift. A theoretical bulge caused by the youngest volcanism at Friday/Domingo seamounts (250 km further west of RCI) is not enough to explain uplift at RCI if realistic values for elastic parameters 
are considered (e.g., Manriquez et al., 2013). Watts and Ten Brink (1989), e.g., proposed the existence of such a bulge $300 \mathrm{~km}$ from the present hotspot on Hawaii Island, which formed in response to subsidence of $1,300 \mathrm{~m}$ at the latter locality over the last 500,000 years (McMurtry et al., 2010). Evidence of $>20 \mathrm{~m}$ uplift is found at Oahu in the now emerged coral reefs (McMurtry et al., 2010). However, there is no evidence of recent Holocene volcanism further west at a distance short enough to promote uplift at RCI. In addition, 3D modeling of the lithospheric flexure seaward of the trench (Manríquez et al., 2013) shows that even more complex loads (seamount loading, bending of the lithosphere near the trench and sedimentary fill inside the trench south of $34^{\circ} \mathrm{S}$ ) do not generate a flexural response beyond $350 \mathrm{~km}$ from the outer rise.

Intrusion at the base of the edifice, as proposed for Canary Islands (Klügel et al., 2005) and Cape Verde (Madeira et al., 2010; Ramalho et al., 2010b) cannot be ruled out. However, because of the absence of volcanism younger than ca. $1 \mathrm{Ma}$ and the rapid displacement of the Nazca Plate we have a reasonable doubt about the occurrence of this process in the Holocene.

Another possibility could be the development of large-scale landslides. The southwestern part of the island is characterized by steep coastal cliffs, and the area lies opposite Santa Clara Island that is thought to have originally formed part of a larger island incorporating RCI (Danton, 2004). The two islands might have been separated during a large-scale landslide event (or events), which in turn may have caused isostatic rebound. The latter is thought to be larger on oceanic plates than on continental plates because of their more limited thickness. In hotspot environments and other high heat-flow areas such as spreading boundaries the asthenosphere should be less viscous, so that rebound rates may increase. Similar events have been reported in Hawaii during the last 2 m.y. (McMurtry et al., 2004). Smith and Wessel (2000) calculated that the removal of $800 \mathrm{~km}^{3}$ of material during the Alika landslide elevated the adjacent terrain by about $17 \mathrm{~m}$, whereas McMurtry et al. (2004) calculated uplift of $109 \mathrm{~m}$ for a volume of 5,000 $\mathrm{km}^{3}$ removed during the Nuuanu landslide. Taking into account an elastic thickness of ca. $10 \mathrm{~km}$ (Manríquez et al., 2013), about $2,000 \mathrm{~km}^{3}$ of material ( $\mathrm{ca}$. $25 \%$ of the initial volume) would thus have had to be removed to account for $>70 \mathrm{~m}$ of uplift at RCI. Such a large mass wasting deposit is not
Comentario [LLP4]: Paragraph added to explain why a bulge, if any, should cause a short-wave anomaly not enough to casuse uplift at $\mathrm{RCl}$
Comentario [LLP5]: Intrusion at the base of the edifice, which cannot be ruled out, is commented and discussed as a theoreticla possibility, which we don't favor because of geological evidence 
evident in the low resolution bathymetry around the RCI, but the caldera-like structure open to the south and some rough relief on the distal flanks suggest that a landslide is a plausible hypothesis.

\section{Conclusions}

Large-scale landslides around ocean islands can probably be attributed to an increase in local slopes generated by the construction of volcanic edifices and the development of rifting. At RCI there has been no major surface volcanic activity since about 3 Ma, with only minor post-shield activity at 0.8 Ma (Lara et al., 2013). Nevertheless, the topography of RCI is even steeper than that of Hawaii, which could have allowed sliding to take place. As modeled by Smith and Wessel (2000), directed giant landslides generate isostatic rebound which is larger over the failed flank and spatially asymmetric. Apparent tilting of the Pliocene volcanic pile could be another expression of this process.

Thus, biostratigraphic evidence of the exposure of former supratidal flats $70 \mathrm{~m}$ above the present sea level, could be related to a large Holocene landslide not previously detected. These findings highlight the importance of biological markers in order to better understand the complex evolution of ocean islands.

\section{Appendix A: Calculation of required wind speed)}

All equations can be found in Le Roux (2005).

Shell density (calcite): $\rho_{\mathrm{s}}=2.85 \mathrm{~g} \mathrm{~cm}^{-3}$.

Shell shape: Ellipsoid, long axis $=1 \mathrm{~cm}$, intermediate axis $=0.75 \mathrm{~cm}$, short axis $=0.35 \mathrm{~cm}$.

Nominal diameter: $D_{n}=\sqrt[3]{(1)(0.75)(0.35)}=0.64 \mathrm{~cm}$

Water density: $\rho_{w}=0.9982 \mathrm{~g} \mathrm{~cm}^{-3}$.

Water dynamic viscosity: $\mu_{w}=0.01 \mathrm{~g} \mathrm{~cm}^{-1} \mathrm{~s}^{-1}$.

Air density: $\rho_{a}=0.0012 \mathrm{~g} \mathrm{~cm}^{-3}$. 
8

Submerged density of shell in water: $\rho_{\gamma}=\rho_{\mathrm{s}}-\rho_{\mathrm{w}}=2.85-0.9982=1.8518 \mathrm{~g} \mathrm{~cm}^{-3}$.

Acceleration due to gravity: $g=981 \mathrm{~cm} \mathrm{~s}^{-2}$.

Dimensionless grain size (water): $D_{d s}=D_{n} \cdot \sqrt[3]{\frac{\rho g \rho_{\gamma}}{\mu^{2}}}=0.64 \cdot \sqrt[3]{\frac{(0.9982)(981)(1.8518)}{(0.01)^{2}}}=168.14$.

Dimensionless settling velocity of nominal sphere in water:

$W_{d s}=\sqrt{2.531 D_{d s}+160}=\sqrt{(2.531)(168.14)+160}=24.2$.

Real settling velocity of nominal sphere in water:

$W_{s}=\frac{W_{d s}}{\sqrt[3]{\rho^{2} / \mu g \rho_{\gamma}}}=\frac{24.2}{\sqrt[3]{(0.9982)^{2} /(0.01)(981)(1.8518)}}=63.69 \mathrm{~cm} \mathrm{~s}^{-1}$.

Real settling velocity of ellipsoid:

$W_{e}=-W_{s}\left\{0.572\left[1-\left(\frac{D_{i}}{D_{l}}\right)\right]^{2.5}-1\right\}=-63.69\left\{0.572\left[1-\left(\frac{0.75}{1}\right)\right]^{2.5}-1\right\}=62.55 \mathrm{~cm} \mathrm{~s}^{-1}$

Dimensionless settling velocity of ellipsoid in water:

$W_{d e}=W_{e} \sqrt[3]{\rho^{2} / \mu g \rho_{\gamma}}=62.55 \sqrt[3]{(0.9982)^{2} /(0.01)(981)(1.8518)}=23.76$

Dimensionless critical shear stress in air for $W_{d e}>11$, assuming that $\beta_{c}$ levels off as in water:

$\beta_{c}=0.00664 \log _{10} W_{d e}+0.00936=(0.00664)(1.3758)+0.00936=0.0185$

Critical shear velocity $U_{*_{C}}$ in air:

$U_{*_{c}}=\sqrt{\frac{\beta_{c} g D \rho_{\gamma}}{\rho}}=\sqrt{\frac{(0.0185)(981)(0.64)(2.85-0.0012)}{0.0012}}=166 \mathrm{~cm} \mathrm{~s}^{-1}$.

Assuming a fully rough boundary, required wind speed measured $10 \mathrm{~m}$ above the ground:

$U_{a}=U_{*_{c}}\left[2.5 \ln \left(\frac{y}{D}\right)+8.5\right]=166\left[2.5 \ln \left(\frac{1000}{0.64}\right)+8.5\right]=4462.9 \mathrm{~cm} \mathrm{~s}^{-1} \approx 160 \mathrm{~km} \mathrm{hr}^{-1}$.

\section{Acknowledgements}


This research was supported by Fondecyt 1110966 project granted to L.E. Lara and is also part of a collaborative effort to better understand fundamental processes in the oceanic islands of the Nazca Plate. J.P. Le Roux worked under the auspices of Project CONICYTFONDAP 15090013. J.C. Baez kindly provided dGPS equipment and data reduction. S.N.

Nielsen and S. Letelier advised on the fossil record. CONAF authorized scientific research in this protected area and DIFROL provided logistical support during the last 2013 field campaign. The referees’s comments are greatly appreciated.

\section{References}

Assereto, R.L.A.M, and Kendall, C.G.St.C.: Nature, origin and classification of peritidal tepee structures and related breccias, Sedimentology, 24, 153-210, 1977.

Bianco, T. A., Ito, G., Becker, J.M., and García, M.O.: Secondary Hawaiian volcanism formed by flexural arch decompression, Geochem. Geophys. Geosyst. (6), Q08009, doi:10.1029/2005GC000945, 2005.

Becker, J.J., Sandwell, D.T., Smith, W.H.F., Braud, J., Binder, B., Depner, J., and Weatherall, P.: Global bathymetry and elevation data at 30 arc seconds resolution: SRTM30_PLUS, Mar Geod, 32(4), 355-371, 2009.

Bindoff, N.L., J. Willebrand, V. Artale, A, Cazenave, J. Gregory, S. Gulev, K. Hanawa, C. Le Quéré, S. Levitus, Y. Nojiri, C.K. Shum, L.D. Talley, and Unnikrishnan, A.: Observations: Oceanic Climate Change and Sea Level, In: Climate Change 2007: The Physical Science Basis. Contribution of Working Group I to the Fourth Assessment Report of the Intergovernmental Panel on Climate Change [Solomon, S., D. Qin, M. Manning, Z. Chen, M. Marquis, K.B. Averyt, M. Tignor and H.L. Miller (eds.)]. Cambridge University Press, Cambridge, United Kingdom and New York, NY, USA, 2007.

Bonatti, E., Harrison, C. G. A., Fisher, D. E., Honnorez, J., Schilling, J. G., Stipp, J. J., and Zentilli, M.: Easter volcanic chain (southeast Pacific): A mantle hot line. J. Geophys. Res., 82(17), 2457-2478, 1977.

Courtillot, V., Davaille, A., Besses, J., and Stock, J.: Three distinct types of hotspots in the Earth’s mantle, Earth Planet Sc Lett, 205, 295-308, 2003. 
Covacevich, V.: Los moluscos pleistocénicos y holocénicos de San Vicente de Tagua Tagua, Memoria de Título (unpublished thesis), Universidad de Chile, Santiago, 1971.

Danton, P.H.: Plantas silvestres de la isla Robinson Crusoe: Guía de Reconocimiento. Corporación Nacional Forestal, Región de Valparaíso, Viña del Mar, 2004.

Davis, B.A.S., Brewer, S., Stevenson, A.C., and Guiot, J.: The temperature of Europe during the Holocene reconstructed from pollen data, Quaternary Sci Rev, 22(15-17), 1701-1716, 2003.

Farley, K. A., A. R. Basu, and Craig, H.: He, Sr and Nd isotopic variations in lavas from the Juan Fernandez Archipelago, SE Pacific, Contrib Mineral Petr, 115 (1), 75-87, 1993.

Fleming, K., Johnston, P., Zwartz, D., Yokoyama, Y., Lambeck, K., and Chappell, J.: Redefining the eustatic sea-level curve since the Last Glacial Maximum using far- and intermediate-field sites, Earth Planet Sc Lett, 163, 327-342, 1998.

Foulger, G.R.: Plates vs. Plumes: A Geological Controversy, Wiley-Blackwell, New York, 364 p., 2010.

Gregory-Wodzicki, K.M.: Uplift history of the Central and Northern Andes: a review, Geol Soc Am Bull, 112, 1091-1105, 2000.

Klügel, A., T. Hansteen, and K. Galipp. Magma storage and underplating beneath Cumbre Vieja volcano, La Palma (Canary Islands). Earth and Planetary Science Letters, 236(12):211-226, 2005.

Koshkarova, V.L., and Koshkarov, A.D.: Regional signatures of changing landscape and climate of northern central Siberia in the Holocene, Russ. Geol. Geophys., 45(6), 672685, 2004.

Lambeck, K., Yokoyama, Y., and Purcell, T.: Into and out of the Last Glacial Maximum: sea-level change during Oxygen Isotope Stages 3 and 2. Quaternary Science Reviews, 21(1), 343-360, 2002.

Lara, L.E., Reyes, J., Piña-Gauthier, M. and Orozco, G.: Geological evidence of a post shield stage at the Juan Fernandez Ridge, Nazca Plate, IAVCEI Scientific Assembly Kagoshima, Abstracts, 2013.

Le Roux, J.P.: Grains in motion: A review, Sedimentary Geology, 178, 285-313, 2005.

Madeira, J., Mata, J., Mourão, C., Brum da Silveira, A., Martins, S., Ramalho, R.S., and D. Hoffmann. Volcano-stratigraphic and structural evolution of Brava Island (Cape Verde) 
from ${ }^{40} \mathrm{Ar} /{ }^{39} \mathrm{Ar}$, U/Th and field constraints. Journal of Volcanology and Geothermal Research, 196(3-4):219-235, 2010.

Manríquez, P., Contreras-Reyes, E., and Osses, A., Lithospheric 3-D flexure modelling of the oceanic plate seaward of the trench using variable elastic thickness, Geophys J Int, ggt464, 2013.

McMurtry, G.M., Campbell, J.F., Fryer, G.J., Smith, J.R., and Fietzke, J.: Uplift of Oahu, Hawaii, during the past 500 k.y. as recorded by elevated reef deposits, Geology, 38, 2730, 2010.

McMurtry, G.M., Watts, P., Fryer, G.J., Smith, J.R., and Imamura, F.: Giant landslides, mega-tsunamis, and paleo-sea level in the Hawaiian Islands, Mar Geol, 203, 219-233, 2004.

Milne, G.A., Long, A.J., and Bassett, S.E.: Modelling Holocene relative sea-level observations from the Caribbean and South America, Quaternary Sci Rev, 24(10-11), 1183-1202, 2005.

Morales, A.: Geología de las islas Robinson Crusoe y Santa Clara, Archipiélago de Juan Fernández, V. Región, Chile: Memoria de Título (unpublished thesis), Universidad Católica del Norte, Antofagasta, 1987.

Montelli, R., Nolet, G., Dahlen, F.A., and Masters, G.: A catalogue of deep mantle plumes: New results from finite-frequency tomography, Geochem Geophy Geosy, 7(11), 2006.

Moore, J.G., S. Jakobsson, and J. Holmjarn: Subsidence of Surtsey Volcano, 1967-1991, Bulletin of Volcanology 55 (1-2), 1992.

Odhner, N.: Mollusca from Juan Fernández and Easter Island, Addenda, in Skottsberg, C. (ed.), The Natural History of Juan Fernández and Easter Island: Almqvist and Wiksells, Uppsala, 1922.

Ramalho, R.S., Quartau, R., Trenhaile, A.S., Mitchell, N.C., Woodroffe, C.D., and Ávila, S.P.: Coastal evolution on volcanic oceanic islands: A complex interplay between volcanism, erosion, sedimentation, sea-level change and biogenic production, Earth- Sci Rev, 127, 140-170, 2013.

Ramalho, R.S., Helffrich, G., Cosca, M., Vance, D., Hoffmann, D. and Schmidt, D.N.: Episodic swell growth inferred from variable uplift of the Cape Verde hotspot islands. Nature Geoscience, 3(11):774-777, 2010a. 
Ramalho, R.S.,Helffrich, G., Schmidt, D.N., and Vance, D.: Tracers of uplift and subsidence in the Cape Verde Archipelago. Journal of the Geological Society, 167(3):519-538, 2010b.

Reimer, P. J., Baillie, M. G. L., Bard, E., Bayliss, A., Beck, J. W., Blackwell, P. G., Bronk Ramsey, C., Buck, C. E., Burr, G. S., Edwards, R. L., Friedrich, M., Grootes, P. M., Guilderson, T. P., Hajdas, I., Heaton, T. J., Hogg, A. G., Hughen, K. A., Kaiser, K. F., Kromer, B., McCormac, F. G., Manning, S. W., Reimer, R. W., Richards, D. A., Southon, J. R., Talamo, S., Turney, C. S. M., van der Plicht, J., and Weyhenmeyer, C. E.: IntCal09 and Marine09 radiocarbon age calibration curves, 0-50,000 years cal BP, Radiocarbon, 51(4), 1111-1150, 2009.

Rodrigo, C. and Lara, L.E.: Plate tectonics and the origin of the Juan Fernández Ridge: analysis of bathymetry and magnetic patterns, Lat. Am. J. Aquat. Res. 42 (4), 2014.

Smith, J.R., and Wessel, P.: Isostatic consequences of giant landslides on the Hawaiian Ridge, Pure Appl Geophys, 157, 1097-1114, 2000.

Ulm, S.: Australian marine reservoir effects: a guide to $\Delta \mathrm{R}$ values, Australian Archaeology, 57-60, 2006.

Valenzuela, E.: Pleistoceno marino en la isla Robinson Crusoe, Comunicaciones, 22, 32-35, 1978.

Von Heune, R., Corvalán, J., Flueh, E.R., Hinz, K., Korstgard, J., Ranero, C.R., and Weinrebe, W.: Tectonic control of the subducting Juan Fernández Ridge on the Andean margin near Valparaíso, Chile, Tectonics, 16(3), 474-488, 1997.

Watts, A.B. and Ten Brink, S.: Crustal structure, flexure, and subsidence history of the Hawaiian Islands: J. Geophys. Res. 94 (B8), 10,473-10,500, 1989. 
Table 1. Radiocarbon dates for gastropods from RCI

\begin{tabular}{|c|c|c|c|c|c|c|c|c|c|}
\hline Site & Sample & Lab. Number & Conventional radiocarbon age & C13/C12 ratio & Calibrated age & Reservoir corrected age & Calibrated age & Material & Elevation \\
\hline & & & (yBP) & & (Cal yBP) $2 \sigma$ & Delta- $R=313 \pm 76$ & $($ Cal yBP $) 2 \sigma$ & & m a.s.l. \\
\hline 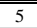 & PS-25-1 & Beta-326738-F & 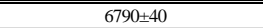 & 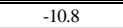 & $77680-7580$ & 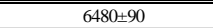 & $7 \overline{7507-7165}$ & Fernandezia & 85.0804 \\
\hline 1 & PS-25-7 & Beta-326739-R & $7860 \pm 40$ & -8.0 & 8320-8030 & $7550 \pm 90$ & 8508-8050 & Nerita & 69.7153 \\
\hline 1 & PS-25-7 & Beta-307410-F & $4580 \pm 30$ & -8.4 & 5440-5090 & $4270 \pm 80$ & 4965-4522 & Succinea & 69.7153 \\
\hline
\end{tabular}

Data obtained at Beta Analytic Inc., Miami, Florida

396

Elevation computed from dGPS data with correction for daily variation of sea level and local height of the antenna

397

398

399

400

401

402

403

404

405

406

407

408

409

410

411

412

413

414

415

416

417

418

419 

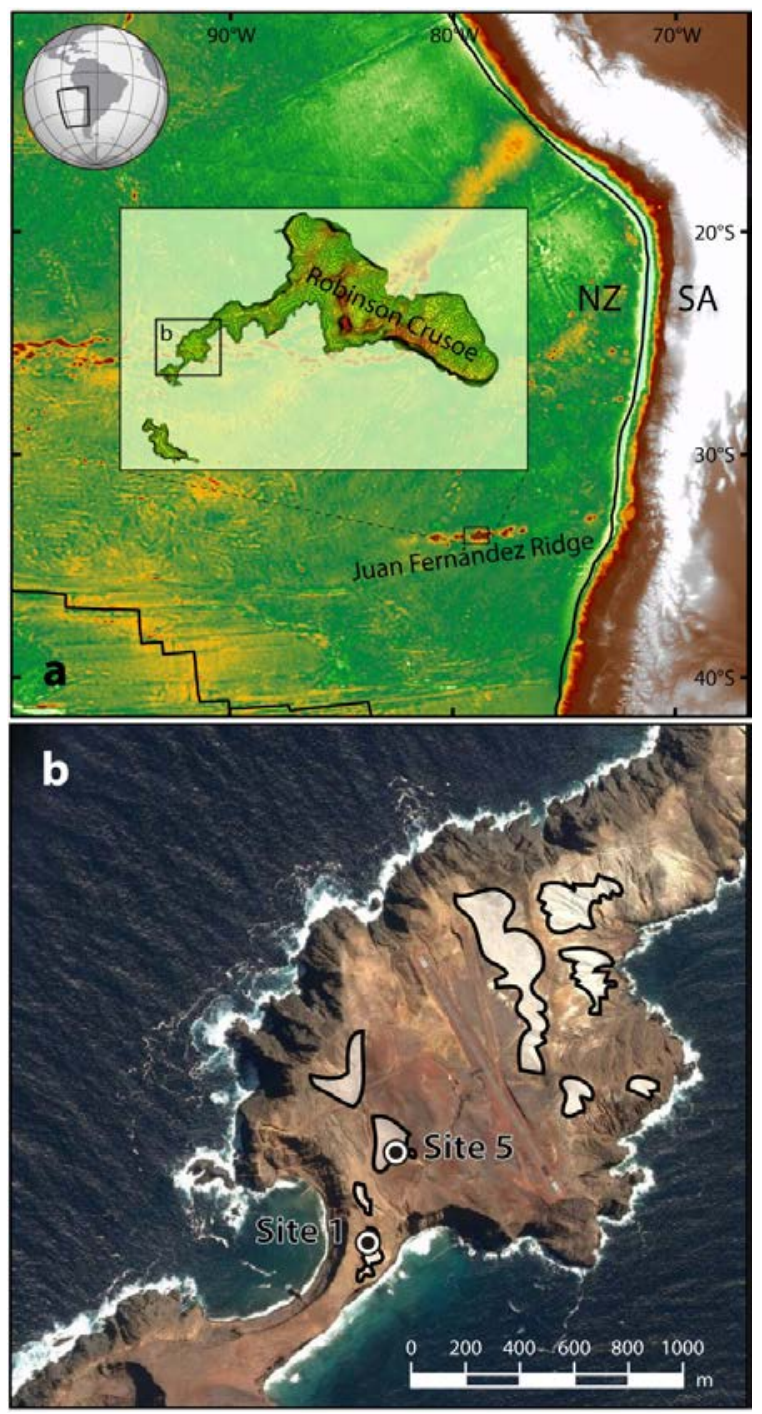

423 Figure 1. Location of Juan Fernández Ridge (a), with Robinson Crusoe Island in a box.

424 Below (b) is a satellite image of the southwestern "panhandle" where the aerodrome is 425 situated. White areas are those of the Bahía Tierra Blanca Formation, where a well exposed 426 supratidal Holocene sequence was dramatically uplifted (see text for details). Sampling 427 sites labeled with numbers (see Table 1). NZ: Nazca Plate: SA: South American Plate. 

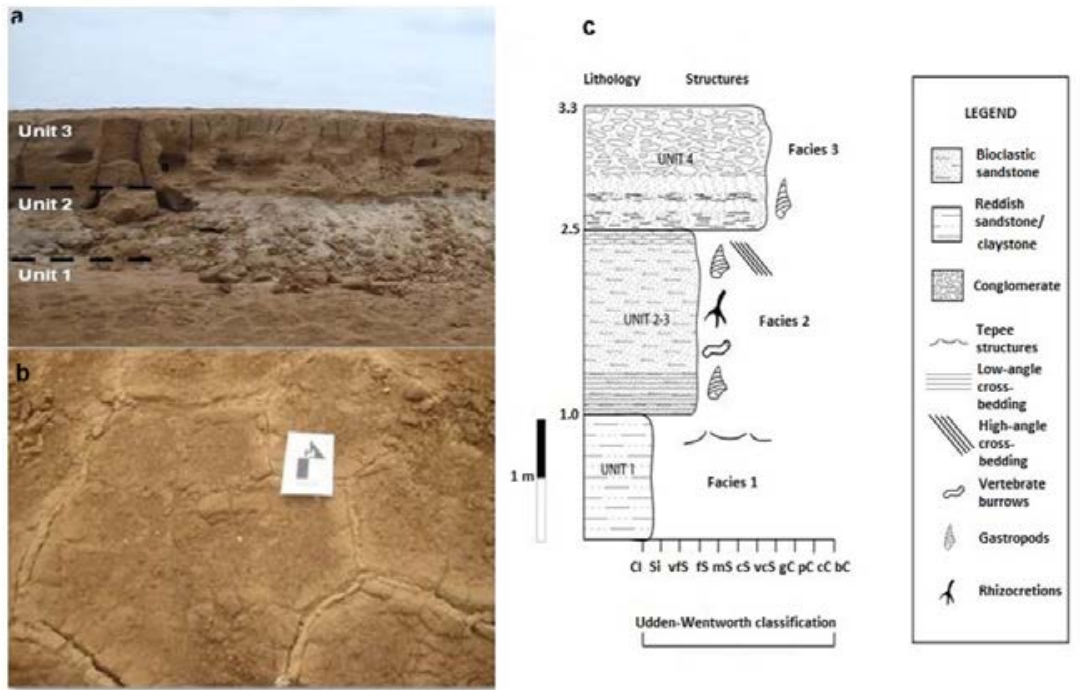

433

Figure. 2. Exposure of sedimentary units as described in text (a). Nerita dated at ca. 8 ka sampled from Unit 1. Below 'teepee’ structures in Unit 1 (b), interpreted as part of a former supratidal flat. A composite stratigraphic column (c) from records at sites shown in Figure 441 1. 


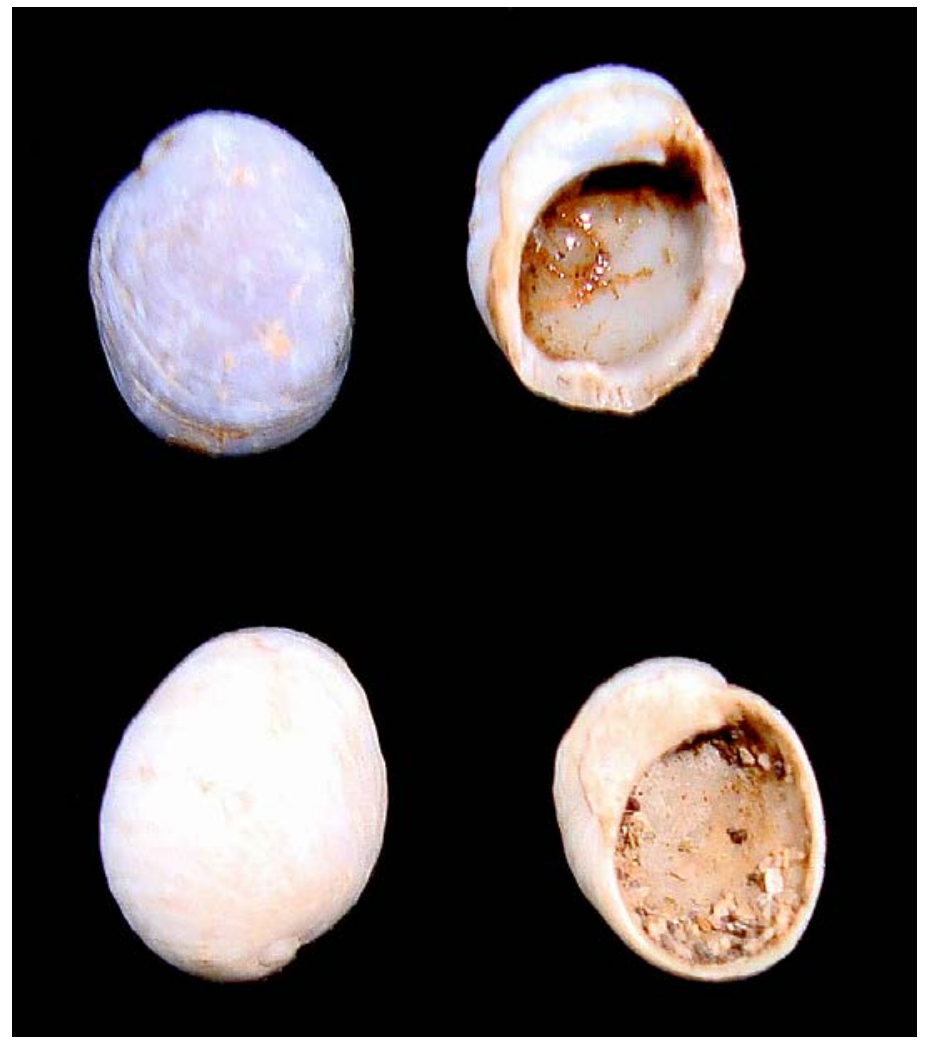

446

451 Figure 3. Nerita shells found in eolian deposits of Unit 2. These are marine species, 452 probably incorporated into dunes developed close to the supratidal flat shoreline. Visual 453 field is $2.5 \mathrm{~cm}$.

454

455

456 